\title{
Macroprudential Policy and Credit Supply
}

\author{
JosÉ-Luis Peydróa
}

JEL-Classification: E58, G01, G21, G28

Keywords: Financial crises, macroprudential policy, credit supply, risk-taking, capital, liquidity

\section{SUMMARY}

In this paper we analyze financial crises and the interactions of macroprudential policy and credit. Financial crises are recurrent systemic phenomena, often triggering deep and long-lasting recessions with large reductions in aggregate welfare, output and employment. Importantly for policy, systemic financial crises are typically not random events triggered by exogenous events, but they tend to occur after periods of rapid, strong credit growth. Moreover, a credit crunch tends to follow in a financial crisis with negative aggregate real effects. Macroprudential policy softens the credit supply cycles, with important positive effects on the aggregate real economy in crisis times.

a ICREA-Universitat Pompeu Fabra, CREI, Barcelona GSE, CEPR, jose.peydro@upf.edu. I thank the Editor for helpful comments and acknowledge financial support from project ECO2012-32434 of the Spanish Ministry of Economics and Competitiveness and the European Research Council Grant (project 648398). 
In 2007, the United States and Western Europe were overwhelmed by a financial (notably banking) systemic crisis, which was followed by a severe economic recession. This sequence of events was not unique: financial crises are recurrent systemic phenomena, often triggering deep and long-lasting recessions with large reductions in aggregate welfare and employment (REINHART and RogofF (2009)). In fact, systemic financial crises are typically not random events caused by exogenous events, but they tend to occur after periods of rapid credit growth in conjunction with other financial imbalances - notably real estate price bubbles (Allen and Gale, 2007; Schularick and Taylor, 2012; Gourinchas and Obstreld, 2012).

Conditional on a financial crisis, these ex-ante debt booms are associated with higher ex-post systemic costs, both within the financial sector (e.g., bank failures) and in the economy at large (e. g., large unemployment or poverty, large fiscal costs, and even political extremism). ${ }^{1}$ Their damaging real effects have generated a broad agreement among academics and policymakers that financial regulation needs to get a macroprudential dimension that aims to lessen the negative externalities from the financial to the macro real sector, as in a credit crunch in a financial crisis caused by the weakening in banks' balance-sheets (both bank capital and liquidity crunch).

Therefore, it is important for policy makers, academics and even citizens to understand the ex-ante determinants of credit booms and their ex-post consequences of credit crunches, and how public policy can ameliorate the likelihood and costs of financial crises. This paper offers a summary on some benefits and costs of some macroprudential policies from a book that I co-authored with Xavier Freixas and Luc Laeven on "Systemic Risk, Crises and Macroprudential Policy" (published last year by MIT Press) and a forthcoming paper at the Journal of Political Economy on "Macroprudential Policy, Countercyclical Bank Capital Buffers and Credit Supply: Evidence from the Spanish Dynamic Provisioning Experiments," co-authored with Gabriel Jiménez, Steven Ongena and Jesús Saurina.

A key message that I want to convey here is that, in order to limit systemic risk effects, it is crucial to reduce excessive debt - leverage levels and acceleration - in times of growth, and to reduce the costs to the economy of excessive debt in times of crisis (mainly because debt is non-contingent, i. e., defaults and renegotiations are difficult).

1 See, for example, Bernanke (1983) and Reinhart and Rogoff (2009). 


\section{What Is Macroprudential Policy?}

Macroprudential policy limits systemic risk over the financial cycle, including a preventive, ex-ante role for the build-up of systemic risk, where systemic risk is the risk of threats to financial stability that impair the functioning of a large part of the financial system with significant adverse effects on the broader economy. Because systemic crises arise from the build-up of financial imbalances (mainly leverage booms) in the financial sector, the ex-ante prevention of excessive risk-taking (not just ex-post crisis management and resolution) should be a crucial objective of public policy, in particular of macroprudential and banking policies.

Moreover, systemic risk normally arises from ex-ante correlated risk choices by individual financial intermediaries and non-financial borrowers (i. e., endogenous systemic risk), not because of risks outside of the financial system (i. e., exogenous risk). Therefore, ex-post crisis interventions, such as central bank liquidity injections via expansive monetary policy or government recapitalizations (bailouts) fail to address the root causes of the systemic crisis, and can even cause higher ex-ante risk-taking via moral hazard, thereby increasing the likelihood of a systemic financial crisis. Nevertheless - while ex-post policies are important to support the liquidity and capital positions of financial institutions and non-financial borrowers (households and firms), the flow of credit to the real economy, and asset prices in crisis times - macroprudential policy applied in booms should be the crucial line of defense to combat systemic risk.

A key question for policy is therefore why excessive endogenous build-ups of debt occur in the first place, both in the financial sector and among non-financial borrowers. There are mainly two root causes. The first is excessive risk-taking in booms mainly by agents (households, banks and firms) being guided by behavioral finance, i. e., not fully rational thinking, such as being overoptimistic in good times, neglecting tail risks with limited memory of previous crises. ${ }^{2}$ The second explanation for the credit and asset price bubbles is poor incentives for excessive risk-taking (moral hazard) of banks and other financial intermediaries which arise from very large leverage and strong explicit and implicit government guarantees (in the extreme case it is like going to a casino to play in order to

2 Yet some of the fluctuations in the preferences for risk-taking can be fully rational, as in habitformation models, where good times make financial intermediaries and non-financial borrowers less risk-averse; they thus take excessive risks in their search for yield. 
privatize the gains but, to a large extent, spreading out the losses among society, which leads to a clear and excessive gambling strategy for the player). ${ }^{3}$

It is important to stress that depending on which one is the most important view of the determinants of excessive risk-taking, optimal public policy will be different. For example, higher bank capital requirements would have positive effects, whether one subscribes to the root cause by increasing buffers in a crisis or not. However, it is mainly in the moral hazard view that higher capital requirements would also reduce ex-ante excessive risk-taking.

Credit (debt, leverage) booms have the strongest ex-ante correlation with the incidence of financial crises in the empirical literature analyzing large historical and cross-country episodes of systemic financial crises. Conditional on the occurrence of a crisis, they increase the negative effects of the crisis upon the real economy. Credit booms, however, can also result from (and promote) sound economic fundamentals and, therefore, be part of the equilibrium growth path, without contributing negatively to systemic risk. For example, research has shown that since the 1970s two-thirds of the credit booms did not produce financial crises. Therefore, it is essential on real time to identify the determinants of the bad (as opposed to good) credit booms that cause financial instability.

Financial crises can be highly damaging not only for the financial system but also for the real economy, as the impairment of the financial system reduces the intermediation of savings to the real economy and the deleveraging of financial institutions puts undue pressures on asset prices and credit flows. Additionally, financial crises tend to follow periods of high leverage for households and nonfinancial firms, and the ensuing debt overhang problems reduce aggregate consumption and investment. Moreover, a decline in aggregate demand feeds back into the financial system by depressing asset prices and collateral values, creating a vicious cycle in which weaknesses in the financial sector and real economy reinforce each other.

Financial crises not only have a strong immediate negative impact on aggregate output and employment, but their negative effects tend to persist over a prolonged period of time, with a recovery to pre-crisis levels of economic activity and wealth often taking several years. A crucial question is therefore what explains the persistency of these financial shocks. Why is it that several countries today have still not recovered to their pre-crisis levels of GDP per capita? Country experiences in handling financial crises have been met with mixed success, with government

3 Most banks have a capital structure with more than $95 \%$ in debt (whereas the typical nonfinancial firm in US has less than $33 \%$ ), and also have deposit insurance, central bank liquidity and bailouts as guarantees from the taxpayers. 
policies sometimes aggravating rather than alleviating problems. Some government policies only target the financial system, such as the creation of a bad bank or bank recapitalization, whereas other policies are more macro oriented, including expansive monetary and fiscal policies. Expansive policies may be beneficial to minimize the short-term impact of a crisis, but have important intergenerational consequences and may plant the seeds for the next bubble. ${ }^{4}$ Other policies, such as forcing banks to hold more capital, may be more effective in good times rather than in crisis times. Structural public policies can also play an important role in restoring financial and economic stability, for instance, policies that foster a more diversified financial system or that increase the flexibility of labor markets.

The real costs of financial crises can be measured in terms of output losses, increases in unemployment, asset prices, fiscal costs associated with bank support measures, and increases in public debt. In the book, and in here, we abstract from the social costs associated with loss of employment and debt overhang problems. Output losses and the increase in public debt capture the overall real and fiscal implications of the crisis.

The costs of financial crises are conditional on potential policy actions taken and are therefore not directly comparable in a strict sense. Also, realized costs do not include taxpayer money put at risk to contain the crisis (including from government guarantees on bank liabilities and subsidized deposit insurance), nor do they capture any wealth transfers associated with accommodative macroeconomic policies to save the banking system (e. g., from creditors to debtors via inflation or low interest rates, or from young to old via increases in public debt). ${ }^{5}$

\section{What Are the Transmission Channels in a Financial Crisis?}

The financial system performs several important functions for the real sector. Therefore, its overall impairment creates several substantial costs for firms and households - for example, ensuring the smooth functioning of the payment system, risk sharing, and saving products. The main transmission channel from financial sector distress is the impairment of the allocation of funds from savers to firms for investment and to households for consumption. This allocation of funds mainly takes the form of bank credit, though in some countries, such as

4 See, for example, Bernanke and Gertler (1995), Bernanke and Blinder (1992), ECB (2009), and AlLEN and Rogoff (2011).

5 See the book and the references therein for a large and important literature on the costs of financial crises. 
Germany and Japan, banks also take equity stakes in firms. Moreover, in some countries financial markets constitute important alternative sources of finance, which are very useful for firms in need of external finance when the banking sector is in distress.

A reduction in credit is an important negative spillover from financial crises (BERNANKe and Lown, 1991). Credit is reduced in a crisis partly because of lack of credit demand as economic perspectives are worse and thus investment opportunities and consumption needs are reduced. However, as firm cash flows are lower in crisis times, the need for external finance in a bust can be higher. Moreover, as collateral and asset prices are lower, agency costs of borrowing are higher, and therefore credit is reduced despite a potential demand for credit. This is also known as the (firm or household) balance sheet channel effect.

Furthermore, systemic crises tend to follow periods of strong credit growth and increasing leverage. Debt overhang problems associated with the crisis and a collapse in asset prices may thus lead to a reduction of aggregate investment and consumption and also reduce access to external finance. Likewise, there may be a strong reduction in risk appetite by financial intermediaries and investors, thus decreasing access possibilites to external finance especially in the case of risky projects, including those needed for a strong recovery of economic growth. Finally, although firms and households may continue to have a positive demand for credit and to be solvent, they may not be able to obtain the necessary credit because bank illiquidity and insolvency may create a reduction of the supply of credit, namely a credit crunch. Contagion within the financial system can further aggravate bank capital shortages and liquidity problems, with funding and market liquidity problems reinforcing each other. In extremely severe systemic crises, the financial system can be so impaired that it is no longer able to perform its main function of attracting savings and channeling them to their most productive use to support investments and consumption, thus implying large real costs.

Banks collect private information from borrowers to make valuable relationship loans, thereby enhancing borrowers' welfare. This information would be lost if banks fail. For example, as we show in our book, there is evidence showing that firms with closer relationships to their banks benefited from easier access to credit from their banks during the Korean financial crisis of 1997. Bank failures therefore create negative externalities for the failed bank's clients through an increase in borrowing cost or credit rationing.

Moreover, firms that lose their main bank relationship during the crisis may suffer disproportionately because surviving banks are at an informational disadvantage and will therefore be reluctant to lend to such firms, especially when 
these firms are small and opaque. Problems in the banking system thus change production decisions of borrowers and this has real effects.

A large empirical literature has shown that financial conditions have real consequences, as we show in our book. For example, there is evidence that the US banking crisis during the Great Depression reduced the efficiency with which credit was allocated, and that the resulting higher cost and reduced availability of credit acted to reduce domestic output by depressing aggregate demand. Though less studied, the real consequences of the European banking crisis in 1931 might have been equally worse, following the collapse in Vienna of Kreditanstalt, which was taken over by the Austrian government. This shook people's confidence not only in other Austrian but also in German banks and was followed by a number of bank failures and corporate bankruptcies which resulted in high unemployment in Germany.

There is also micro level evidence. For example, Jiménez et al. (2012) analyze the credit crunch in the 2008 crisis in Spain using a dataset consisting of loan applications. To establish a causal link between bank balance sheet strength and credit supply, they focus on the set of loan applications made in the same month by the same borrower to different banks of varying balance-sheet strengths. Within this set of loan applications, for which the quality of potential borrowers is constant, they study how economic conditions that affect the granting of loans vary with bank capital and liquidity conditions. Moreover, they analyze whether firms that get rejected in their initial loan application can undo the resultant reduction in credit availability by successfully applying to other banks. (If that was the case, then it would imply that the real effects associated with credit crunches are minimal.)

They find that lower GDP growth reduces the probability that a loan application is granted, particularly during crisis times. The negative effect on loan granting is statistically stronger for banks with low capital, implying that a bank capital crunch leads to a credit crunch. They also find that firms that get rejected in their initial loan application cannot undo the resultant reduction in credit availability by applying to other banks, especially in periods of tighter economic conditions.

All in all, both excessive credit booms and credit crunches in financial crises are damaging for systemic risk. Some key instruments (that I want to highlight) to reduce excessive leverage in booms and to reduce the costs in the real economy once the crisis arrives are respectively: (i) eliminating or reducing the debt tax shields in favor of debt over equity (debt interest payments over dividends), or in buying versus renting houses (as it happened in Spain during the crisis); (ii) increasing bank capital as in Basel III; (iii) loans without full recourse as in most states in US; (iv) expansive monetary policy via conventional reduction 
in monetary short-term interest rates and some unconventional policies such as quantitative easing and reducing long-term interest rates (these expansive policies favor debtors over creditors); (v) allowing more loan defaults (including household, bank and country bankruptcy procedures, which are slowly progressing); (vi) countercyclical capital requirements (even the dynamic provisioning from the Bank of Spain); and (vii) maybe potential bailouts of borrowers and lenders, though this should be the last line of policy. It is important to stress that these policies are fiscal via changes in taxes or bailouts and that some unconventional monetary policies increase the risk of losses for the central bank more indirectly, or require less taxpayer funds in the case of higher bank capital (and thus higher bank buffers to withstand a crisis or a potential reduction in crises as bank shareholders lose much more in case of excessive risk).

Finally, some public policies on the European level are advancing, notably the Banking Union, where we have progress on reducing the risk of bailouts of banks by taxpayers by increasing bail-in principles, as we saw in the resolution of the Cyprus crisis. This will reduce the diabolic loop of banks-sovereign problems. There are still limitations in the current banking union, notably on deposit insurance, whereas there has been strong progress on the ECB being the common supervisor. Moreover, there are other interesting policies in Europe. For example, the Macroeconomic Imbalance Procedure is a surveillance mechanism that aims to identify potential risks early on, prevent the emergence of harmful macroeconomic imbalances and correct the imbalances that are already in place, notably external, such as current account deficits and strong capital inflows, as well as internal, such as excessive credit booms and real estate price acceleration.

All in all, at both the local and international level, we need better public policy - a combination of banking, macroprudential, monetary and fiscal policies - to reduce the likelihood and negative consequences of financial crises. In the rest of this paper, I want to concentrate on countercyclical capital requirements, with some evidence from Spain, to analyze in detail how macroprudential policy can affect credit supply and in turn the real economy. 


\section{Macroprudential Policy in Action}

As credit cycles are key for systemic risk, time-varying macroprudential policy tools can be used to address these cyclical vulnerabilities in systemic risk. ${ }^{6}$ Under the new international regulatory framework for banks - Basel III - regulators agreed to vary minimum capital requirements over the cycle, by instituting countercyclical bank capital buffers (i. e., pro-cyclical capital requirements), which aim to achieve two macroprudential objectives at once. First, boosting equity or provisioning requirements in booms provides additional (countercyclical) buffers in downturns that can help mitigate credit crunches. Second, higher requirements on bank own funds can cool credit-led booms, either due to the higher cost of bank capital or because banks internalize more of the potential social costs of credit defaults (via lower moral hazard by having more "skin in the game").

Countercyclical buffers could hence lessen the excessive pro-cyclicality of credit, i. e., those credit cycles that find their root causes in banks' agency frictions. Smoothing credit supply cycles will cause positive firm-level real effects if bank-firm relationships are valuable and credit substitution for firms is difficult in bad times.

Despite the attention now given by academics and policymakers alike to the global development of macroprudential policies, no empirical study so far has estimated the impact of a time-varying macroprudential policy tool on the supply of credit and the associated spillovers on real activity in both good and bad times. Jimenez et al. (2015) attempts to fill this void by analyzing a series of pioneering policy experiments with dynamic provisioning in Spain: From its introduction in 2000:Q3, and change in 2005:Q1 during good times, to its later performance when a severe (mostly unforeseen) crisis shock struck, thus allowing a test of the countercyclical nature of the policy, and also the changes in bad times (the two reductions in 2008:Q4 and in 2009:Q4, and an ad hoc increase in provisions in 2012:Q1 and Q2). These shocks coupled with unique bank-, firm-, and loanlevel (and loan application) data allow for identification.

Dynamic provisions - called "dynamic" as they vary over the cycle and "statistical" or "generic" as a formula is mandating their calculation - are forwardlooking: Before any credit loss is recognized on an individual loan, a buffer (i. e.,

6 This last section summarizes Jiménez, Ongena, Peydró and Saurina (2015). Macroprudential policy, countercyclical bank capital buffers and credit supply: Evidence from the Spanish dynamic provisioning experiments. Mimeo. UPF. Forthcoming at the Journal of Political Economy. 
the dynamic provision fund) is built up from retained profits in good times to cover the realized losses in bad times (i. e., when specific provisions surpass its formula-based average over a credit cycle). The dynamic provision fund has a regulatory ceiling and floor. The required provisioning in good times is over and above the specific loan loss provisions and there is a regulatory reduction of this provisioning in bad times, when bank profits are low and new shareholders' funds are costly to obtain. Dynamic provision funds are now Tier-2 regulatory capital. Hence, dynamic provisions are pro-cyclical, thus constituting countercyclical capital buffers to be used in crisis times.

The policy experiment in good times that JiMENEz et al. (2015) focus on is the introduction of dynamic provisioning in 2000:Q3, which by construction entailed an additional non-zero provision requirement for most banks, but and this is crucial for the estimation purposes - with a widely different formulabased provision requirement across banks. Next, the authors analyze the countercyclical workings of the dynamic provision funds built up by the banks as of 2007:Q4 following the crisis shock in 2008:Q3. The authors also follow a series of policy experiments in bad times, i. e., the sudden lowering of the floor of the dynamic provision funds from 33 to $10 \%$ in 2008:Q4 and to 0\% in 2009:Q4 (that allowed for a greater release of buffers for many banks). Given that the overall pre-crisis level of provisions was relatively low (1.25\% of total credit) and basically depleted in 2011, the 2012 increase in provisioning that banks needed to make was based on their exposure to construction and real-estate firms to clean up their balance sheets.

To identify the availability of credit and the associated real effects, Jimenez et al. (2015) employ a comprehensive credit register that comprises bank-firm level data on all outstanding business loan contracts and balance sheets of all banks collected by the supervisor, in conjunction with firm-level data from the Spanish Mercantile Register. The authors calculate the total credit exposures by each bank to each firm in each quarter, from 1999:Q1 to 2013:Q3, a time period which allows us to study the impact of dynamic provisions along a full cycle, with an unexpected crisis in the middle. The paper analyzes changes in committed credit volume, on both the intensive and extensive margins, and also credit drawn, maturity, collateral and cost, and also uses the granting of loan applications made by firms to new banks to analyze substitution effects. Depending on their credit portfolio, banks were differentially affected by the various policy experiments. Therefore, the authors perform a difference-in-differences analysis where they compare before and after each shock differently affected banks' lending at the same time to the same firm. Though the authors analyze the same bank (-firm) before and after the shock, in robustness they further control for 
up to 32 bank variables and key bank-firm and loan characteristics. They also exploit differences across various subsamples, components of the risk formula, and regulation (i.e., foreign branches in Spain were not regulated with respect to dynamic provisioning). Finally, by matching credit with firm balance sheets and the register on firm deaths, they also assess the effects on firm-level total assets, employment and survival.

In good times Jimenez et al. (2015) find that banks that have to provision more cut committed credit more to the same firm after the shock - and not before than other banks. These findings also hold for the extensive margin of credit and for credit drawn, maturity, collateral, and credit drawn over committed (an indirect measure of the cost of credit). Hence, pro-cyclical bank capital regulation in good times contracts credit supply.

These findings are robust. For example, first, the authors apply the new provision formula to each bank's credit portfolio in 1998:Q4, well before any discussion on the policy had taken place, rather than in 2000:Q3, when dynamic provisioning became compulsory. Second, they exclude banks of direct interest to policy-makers, i. e., the savings or the very large banks, as policy-makers capable of accurately predicting the heterogeneous changes in bank credit could have devised the formula to maximize its impact. Third, to allay any remaining endogeneity concerns, they exploit the opposite implications of the formula related to bank risk and also assess how unregulated foreign branches react as compared to what regulated foreign subsidiaries or domestic banks do. Fourth, to understand the economic channel, they analyze how credit responds to realized overall provisions instrumented with the formula-based provisioning. Fifth, by using firm observables, firm fixed effects or no firm controls, they assess the degree to which the credit supply shock is orthogonal to observed and unobserved demand fundamentals.

But are firms really affected in good times? Jimenez et al. (2015) find mostly not. Though total committed credit availability by firms drops immediately following the introduction of dynamic provisioning, three quarters afterwards there is no discernible contraction of credit available to firms, as firms easily substitute credit from less affected banks (from both new banks and banks with an existing relationship). Consistently, the authors find no impact on firm total assets, employment, or survival.

Yet, while average firms are not significantly affected, there are important changes in the allocation of credit supply. After the policy shock, banks with higher requirements focus their credit supply more to firms with a higher ex-ante interest paid and leverage, and with higher ex-post default, thus suggesting that higher capital requirements may increase bank risk-taking and searching-for-yield. 
This may be an unexpected but likely unintended consequence of this regulatory intervention. Moreover, the negative impact of higher requirements on credit is stronger for smaller firms and banks, which struggle more to absorb the shock.

In bad times things look very different. Banks with higher pre-crisis dynamic provision funds, stemming from policy, increase their supply of committed credit to the same firm permanently over the whole period 2009-10 (i. e., capital buffers mitigate the credit crunch). Similar findings hold for credit continuation, drawn and drawn over committed (i. e., implying a lower cost of credit), and again for numerous alterations in specification and instrumentation (as for example instrumenting pre-crisis buffers with initial policy provisioning from 2000). Results, moreover, suggest that the mechanism at work is through saving capital in crisis times, when profits and shareholder funds are scarce and costly. In addition, banks with dynamic provision funds below ceiling (and hence that benefited most from the lowering of the floor in 2008:Q4 and in 2009:Q4 as they can immediately release capital funds) increase their credit supply only in the quarters around the policy changes. These banks also tighten maturity and collateral, possibly to compensate for the higher risk taken by easing volume.

Strikingly different in bad times (from good times) is that the changes in bankfirm level credit are binding at the firm-level; credit availability permanently contracts more for those firms that borrowed more from banks that, when the crisis hit, had lower dynamic provision funds stemming from policy. Results with granting of loan applications show that firms cannot substitute for lost bank financing. Consistent with this, the authors find that firm total employment and survival are negatively affected as well. The estimates also imply economi$\mathrm{cal}$ relevancy. Firms dealing with banks holding 1 percentage point (pp) more in dynamic provisioning funds (over loans) receive 9 pp more in committed credit than when dealing with other banks, have a 6 pp higher growth in the number of employees and a 1 pp higher likelihood of survival. In sum, banks with higher capital buffers, stemming from the stricter regulatory requirements in good times that can be drawn down in bad times, partly mitigate the deleterious impact of the financial crisis on the supply of credit and the associated real effects.

Compositional changes in credit supply are again important. Bank risk-taking also differs between higher pre-crisis capital buffers versus softer requirements on lowly capitalized banks. In the latter case, more credit is supplied to more levered firms and firms with long-term (client) relationships, consistent with risk-shifting strategies related to zombie lending or gambling for resurrection. Hence, real and risk-taking effects are not the same when the regulator increases requirements in good times to have higher buffers in bad times, than when she simply reduces them in bad times. Also the positive effects on credit from countercyclical buffers 
are lower when bank non-performing loans and leverage ratios are higher, thus suggesting a binding market constraint for weaker banks.

Finally, Jimenez et al. (2015) analyze the increase in provisions in 2012 that banks had to make based on their lending exposure in 2011 to construction and real-estate firms. The impact on credit supplied to firms not in construction or real-estate is immediate and binding (again, the granting of loan applications shows that credit substitution is difficult). These firms are subsequently negatively affected in their survival. Firms that dealt with banks that, on average, face $1 \mathrm{pp}$ more tightening in requirements suffer a contraction of at least $4 \mathrm{pp}$ in committed credit availability and a $1 \mathrm{pp}$ of survival. Significant effects occur only after the policy change and not before. Moreover, the credit crunch is softer by lowly capitalized banks with high NPLs ratios and for firms with worse credit history and profits, consistent with risk-shifting by the banks more affected by the policy.

\section{Conclusions}

All in all, responding to the urgent interest among policymakers and academics, JimENEZ et al. (2015) is the first empirical paper to actually estimate the impact of a macroprudential policy on credit supply cycles and their associated real effects. The robust evidence shows that countercyclical bank capital buffers mitigate cycles in credit supply and have a positive effect on firm-level aggregate financing and performance. In bad times switching between banks is difficult, thus firms will be more affected by capital shocks. Hence, the aggregate level of capital and its distribution across banks matters. Tightening capital requirements in bad times is much more contractive for credit and real output than it is in good times. Building up capital buffers before the crisis is superior in terms of maintaining real activity and avoiding risk-shifting than changing requirements (for lowly capitalized banks) during the crisis, as the evidence from the floor reductions in 2008-09 and the increase in 2012 suggests. However, a capital tightening in good times can induce both risk-taking by regulated banks (that supply more credit to firms with higher both ex-ante yield and leverage and ex-post defaults) and regulatory arbitrage by non-regulated and regulated-but-less-affected banks. 


\section{References}

Allen, F., and D. Gale (2007), Understanding Financial Crises, New York.

Allen, F., and K. Rogoff (2011), "Asset Prices, Financial Stability and Monetary Policy", in The Riksbank's Inquiry into the Risks in the Swedish Housing Market, P. Jansson and M. Persson, eds., Stockholm, pp. 189-218.

Bernanke, B. (1983), "Nonmonetary Effects of the Financial Crisis in Propagation of the Great Depression", American Economic Review, 73(3), pp. 257-276.

Bernanke, B., and M. Gertler (1995), "Inside the Black Box: The Credit Channel of Monetary Policy Transmission", Journal of Economic Perspectives, 9(4), pp. 27-48.

Bernanke, B., and A. Blinder (1992), "The Federal Funds Rate and the Channels of Monetary Transmission”, American Economic Review, 82, pp. 901-921.

Bernanke, B., and C. Lown (1991), "Credit Crunch", Brookings Papers on Economic Activity, 22, pp. 205-248.

European Central Bank (2009), "Recent Developments in the Balance Sheets of the Eurosystem, the Federal Reserve System and the Bank of Japan”, ECB Monthly Bulletin, October, pp. 81-94.

Freixas, X., L. Laeven, and J.-L. Peydró (2015), Systemic Risk, Crises and Macroprudential Policy, Cambridge.

Gourinchas, P.-O., and M. Obstfeld (2012), "Stories of the Twentieth Century for the Twenty-First", American Economic Journal: Macroeconomics, 4(1), pp. 226-265.

Jiménez, G., S. Ongena, J.-L. Peydró, and J. Saurina (2014), "Hazardous Times for Monetary Policy: What do Twenty-Three Million Bank Loans Say about the Effects of Monetary Policy on Credit Risk-Taking?", Econometrica, 82(2), pp. 463-505.

Jiménez, G., S. Ongena, J.-L. Peydró, and J. Saurina (2012), “Credit Supply and Monetary Policy: Identifying the Bank Balance-Sheet Channel with Loan Applications", American Economic Review, 102, pp. 2301-2326.

Jiménez, G., S. Ongena, J.-L. Peydró, and J. Saurina (2015), “Macroprudential Policy, Countercyclical Bank Capital Buffers and Credit Supply: Evidence from the Spanish Dynamic Provisioning Experiments", Journal of Political Economy, forthcoming.

Reinhart, C., and K. Rogoff (2009), This Time is Different: Eight Centuries of Financial Folly, Princeton University Press.

Schularick, M., and A. M. Taylor (2012), "Credit Booms Gone Bust: Monetary Policy, Leverage Cycles, and Financial Crises, 1870-2008”, American Economic Review, 102, pp. 1029-1061. 